Jan Rutkowski*

ORCID: 0000-0002-3347-9420

Warsaw, Poland

\title{
Moral Education in the Perspective of Liberal Education, Natural Law and the Modern Doctrine of Social Contract
}

\author{
Wychowanie moralne w perspektywie \\ kształcenia ogólnego, prawa naturalnego \\ i koncepcji umowy społecznej
}

Summary: This article includes an analysis of relationship between concepts of moral education, liberal education and natural law. It shows how classical Greek philosophy influenced Christian thought. Moreover, there is consideration regarding what has changed in the understanding the concept of virtue.

Keywords: natural law; moral education; liberal education; social contract; virtue.

Streszczenie: Artykuł zawiera analizę relacji między pojęciami kształcenia ogólnego, wychowania moralnego oraz prawa naturalnego. W tekście pokazano

* Dr hab. Jan Rutkowski - assistant professor at the University of Warsaw, Faculty of Education, General Pedagogy and Philosophy of Education Section. Address: ul. Mokotowska 16/20, 00-561 Warsaw, Poland; email: jrutkowski@uw.edu.pl 
również wpływ klasycznej filozofii greckiej na myśl chrześcijańską. Ponadto, prześledzono zmiany rozumienia pojęcia cnoty.

Słowa kluczowe: prawo naturalne; wychowanie moralne; kształcenie ogólne; umowa społeczna; cnota.

What is moral education in the perspective of liberal education? The ambiguity of this notion is sometimes the cause of some confusion that is usually present in the pedagogical discussions. When discussing liberal education we often think of education as part of a liberal system. Concurrently, this term is used to describe permissive education that is against traditional morality. However, the most basic understanding of the concept of liberal education is general education. From this perspective, the goal of liberal education is to form man, his character, and his conscience. In religious pedagogy, it is usually described as formation.

The aforementioned examples of situations in which the expression "liberal" appears in the context of education allows us to assume that, apparently referring to the same notion, in reality educators often assume different, even competitive, visions of the world and the purpose and meaning of human life. There may be a misunderstanding because nowadays the term "liberal" has different connotations from those of ancient thinkers. According to Leo Strauss, the original political meaning of the term liberal is almost exactly the opposite of what it is now ${ }^{1}$. Let us first examine the ancient definition of education. For classical philosophers, the liberal was a man who behaved like a free man rather than a slave. The slave does not live for himself and cannot manage his own life according to his own will. He lives for someone else. Additionally, a man forced to work for his own livelihood is not free. $\mathrm{He}$ works so that he is able to survive and then he rests to gain strength to work.

\section{Two traditions}

Until recently, education in Western culture was shaped by two competing and, to a certain extent, complementary traditions. The first is the

${ }^{1}$ Leo Strauss, Liberalism Ancient and Modern (Chicago-London: The University of Chicago Press, 1995). 
classical natural law theory. According to Strauss, it can be described as the detailed classical natural law theory, initiated by Socrates, and developed by Plato, Aristotle, Stoics and Christian thinkers (especially Thomas Aquinas). The classical natural law theory must be distinguished from the modern doctrine of natural right, which was established in the seventeenth century and developed in the following one ${ }^{2}$.

The second, competitive tradition that forms the philosophical foundations of pedagogy is the modern doctrine of social contract. On the one hand, Western thinking about education is founded on the vision of the world of human affairs anchored in the natural order of things; on the other hand, the state, law, morality, and in extreme cases, humanity itself, is treated as a conventional product of social contract. Until recently, both traditions (in a specific tension) formed identity of Western culture, including the sphere of education. From this perspective, the specifics of the West stem from the classical natural law theory and from the contractual doctrine of the social contract. Cutting off one of these sources disturbs the balance and raises the question of the cultural identity of the West.

\section{Greek philosophy and Christianity}

Despite significant differences, it can be said that both classical Greek philosophy and Christian thought generally agreed that there were universal measures, and the world harmony independent and prior to human will. In his famous work The Consolation of Philosophy, Anicius Manlius Severinus Boethius combines philosophical and Christian attitude. Boethius, waiting in prison for his execution, is consoled by a personification of Philosophy. The key moment in the discussion is the question of the world order. The standpoint suggesting that the soul's health depends on the belief in the world order is an important passage of the text. Philosophy comforts a distressed prisoner:

You have forgotten by what methods the universe is guided; hence you think that the chances of good and bad fortune are tossed about with no ruling hand. These things may lead not to disease only, but even to death as well. But let us thank the Giver of all health, that your nature has not altogether left you. We

${ }^{2}$ Leo Strauss, Natural Right and History (Chicago: The University of Chicago Press, 1971). 
have yet the chief spark for your health's fire, for you have a true knowledge of the hand that guides the universe: you do believe that its government is not subject to random chance, but to divine reason. Therefore have no fear. From this tiny spark the fire of life shall forthwith shine upon you ${ }^{3}$.

\section{Philosophy as a way of life}

According to Pierre Hadot, philosophy is primarily a way of life and a kind of spiritual exercise. The philosophical schools required total commitment from their students. They exhorted for conversion and spiritual transformation (metanoia) - competing both with each other and with Christianity, as the ways of life ${ }^{4}$. Contrary to the scholastic interpretations of philosophy as purely theoretical activity ${ }^{5}$, we now know that the ancient philosophy fully deserves the name the way of life. Philosophical schools offered their students not only theoretical knowledge but a coherent vision of the world, as well as cosmological knowledge, detailed moral guidelines and even dietary recommendations. According to Karłowicz: "In many respects, the spirit of ancient philosophical schools is easier to find today in monasteries than in universities - especially when we consider the constant effort of moral and intellectual exercises (askesis) to transform the knowledge and life of students of philosophy."'6

Werner Jaeger compares the missionary activity of St. Paul to the activity of philosophical schools and emphasises their significant similarities:

The various schools tried to find followers by making protreptic speeches in which recommended their philosophical knowledge or dogma as the only way to happiness. We find this kind of eloquence first in the teaching of the Greek sophists and of Socrates as he appears in the dialogues of Plato. Even the word "conversion" stems from Plato, for adopting a philosophy meant a change of

${ }^{3}$ Anicius Manlius Severinus Boethius, The Consolation of Philosophy, trans. W. V. Cooper (2009), I, VI, p. 16, https://www.exclassics.com/consol/consol.pdf [access: 5.11.2019].

${ }^{4}$ Pierre Hadot, Czym jest filozofia starożytna?, trans. Piotr Domański (Warszawa: Fundacja Aletheia, 2000), 95-103.

5 Pierre Hadot, Filozofia jako ćwiczenie duchowe, trans. Piotr Domański (Warszawa: Fundacja Aletheia, 2003), 294-296.

${ }^{6}$ Dariusz Karłowicz, Sokrates i inni święci (Warszawa: Wydawnictwo Fronda i Ośrodek Myśli Politycznej, 2005), 25. 
life in the first place. Even though the acceptance of it was motivated differently, the Christian kerygma spoke of the ignorance of men and promised to give them a better knowledge, and, like all philosophies, it referred to a master and teacher who possessed and revealed the truth. ${ }^{7}$

Philosophy and Christianity are seen as a way of life requiring total commitment; however, they promise the greatest available human happiness in return. Nonetheless, even monks should remember about the complexity of human nature and therefore should not neglect the basic needs of the body $^{8}$. It is impossible to be a philosopher or a Christian following the truth only during working hours or "part-time".

Both Christians and the representatives of philosophical schools assumed that there were moral laws that were independent of human will, resulting from the order of the world. All of them essentially rejected conventionalism, which dominates today. The conviction that all rights are the only result of the contract is not a modern discovery, although it desires to be considered as the ultimate stage of development of modern ethical and legal consciousness. Classical philosophers were not as naive as they are seen today by modern intellectuals who are lured by the idea of progress. Classical philosophers predicted "modern solutions". However, they rejected them as unrealistic and in consequence self-destructive.

\section{The discovery of nature}

It can be said that the most important discovery of classical Greek philosophy, and simultaneously its beginning, is the discovery of nature. The question about the primordial world of pre-principle (arche) is to be considered as the beginning of the freeing of a thinking man from his natural, mythically interpreted faith ${ }^{9}$. Joseph Ratzinger mentions various ways of "breaking away from the myth", on the one hand, the "monotheistic revolution" founded on the Bible, and on the other hand, the path of "enlighten-

7 Werner Jaeger, Early Christianity and Greek Paideia (Harvard University Press, 1985), 10.

8 Jan Kasjan, Rozmowy z Ojcami, trans. Arkadiusz Nocoń (Kraków: Wydawnictwo Benedyktynów Tyniec, 2002), 179-205.

${ }^{9}$ Hans-Michael Baumgartner, Rozum skończony. Ku rozumieniu filozofii przez siebie sama, trans. Andrzej Maciej Kaniowski (Warszawa: Oficyna Naukowa, 1996), 100. 
ment" of absolutising rational cognition. This second way was first realised in classical Greece ${ }^{10}$. According to Strauss, philosophy unlike the myth was born when nature was discovered, or the first philosopher was the man who first discovered nature ${ }^{11}$.

The first step to discovering nature was the empirical observation that everything that exists has its regular "habits", or otherwise "ways". However, these paths are not compatible with each other. The laws, customs and rituals sanctified by the traditions of one nation bring horror and disgust in other societies. So the question is, which way of life is right?

Today, this controversy is irrelevant before it appears. The pluralism of cultures, customs and norms necessarily implies relativism. The pluralism of customs, lifestyles or ethical systems allegedly does not allow a search for universal "ways" or "habits." In this perspective, the question about universal measure appears to be - at best - a result of ignorance. Even worse, it can also be interpreted as an oppressive attempt to impose its own, particularistic to use postmodern jargon, "meta-narration".

The classical natural law theory foresees this type of reasoning, but challenges it and rejects it. The importance of the discovery of nature escapes our attention when nature is understood as the "whole of phenomena". The pre-philosophical notion of "custom" or "way" is broken down into categories of "nature" on the one hand and "convention" on the other. There is a world of first things and a world of human products. Things made by man only lead to a man who is certainly not the first thing. Human hand products appear to be lower in every way or later than things that a man did not make but found or discovered ${ }^{12}$. The question about natural law is motivated by the desire to find what is good by nature, as opposed to what is good only on the basis of the convention. One law praises acts that another categorically condemns. One law calls for the sacrifice of the firstborn son, while the other laws forbid all human sacrifices as something disgusting.

Man is obviously not his own product. However, he lives in a "Cave" of convention and socially shared opinions $($ doxa $)$. The Platonic parable of the Cave shows that philosophy is the exiting of the Cave, it is the transition from the opinion to the truth. It is also a model of education which, in its proper and highest form, becomes identical with philosophy.

${ }^{10}$ Joseph Ratzinger, Truth and Tolerance. Christian Belief and World Religions (San Francisco: Ignatius Press, 2004).

${ }^{11}$ Strauss, Natural Right.

12 Ibidem. 
A well-educated man is a properly formed man. A crucial aspect is the proper order of the soul; what is higher is to guide the lower layers of the soul. Cognition of human nature is available for rational reflection. There is neither wise nor morally good treatment of beings against their nature. Human knowledge may, however, be disturbed by passions or lusts. This is why it is necessary to order the soul of man, which implies the natural hierarchy of human activities.

For Aristotle, the question about human nature is related to the question about the essence of humanity. Since reason and speech distinguish man from other biological entities, the same activities that engage in reason (contemplation) and speech (political activity) become the most important in the perspective of the realisation of the essence of humanity. They also give the greatest possible happiness available to man as man.

Aristotle, like his master Plato, is convinced that the life of a philosopher is best for man. He must, as Hans-Georg Gadamer observes, give priority to the ideal of theoretical life opposed to practice and politics ${ }^{13}$. Concurrently, however, he adds that the other type of excellence is political activity. Theoretical contemplation stands above political activity because of the ontological superiority of its object: that which exists always. Practice deals with the sphere of what is alternating, unnecessary, contingent, incomplete, "partial". However, because of his finite, conditioned and complex nature, man cannot devote himself completely and entirely to theoretical contemplation.

\section{Virtue}

Modernity in its origins did not negate virtue itself. On the contrary, there were often appeals for the restoration and renewal of the classical virtue allegedly lost by formalised scholastic philosophy. Initially, there was opposition against scholastic interpretations. Classical concepts of Greek philosophy were to be cleared of scholastic distortions. This project has been successful too much. It not only negated the scholastic interpretations of virtue but even virtue itself. The range of the term virtue's meaning was narrowed and eventually virtue was ridiculed. In consequence, it undermined the purpose of moral education.

${ }_{13}$ Hans-Georg Gadamer, The Idea of the Good in Platonic-Aristotelian Philosophy (Yale University Press, 1986). 
The good analogy of this strategy of action is described by Charles Taylor's criticisms formulated by the reformation in relation to monastic life. Religious life was accused of hubris and elitism. Recognising a higher type of vocation, the "elitist path", allegedly brought hubris and self-deception to the monk. The affirmation of everyday life and all that serves it, characteristic of modernity, has, according to Taylor, its source in a certain type of Christian devotion ${ }^{14}$. The higher forms of activity were perceived as founded on hubris, the hubris which came from the classical philosophers.

In this perspective, the "fault" of Christianity, and especially the Catholic Church, was subordinating to the influence of Greek philosophy. Ever since the Reformation time, people have been suspicious of the philosophical robe of Rome. Has Revelation not been betrayed by philosophers, who turned out to be philosophers rather than Christians? Additionally, we can find theories from the twentieth century claiming that ancient philosophical concepts penetrated Christian thought and distorted Revelation. According to Adolf Harnack: "Roman Catholicism has nothing to do with the Gospel. [...] It is a great insurance company protecting Plato's and Zenon's ideas because the dogma of the church assumes Plato's and a stoic vision of the world, long ago overthrown by science." 15 The Catholic Church appears to be - perhaps one of the last - depositaries of the tradition of classical Greek philosophy, which is also admitted by thinkers resistant to Catholicism. In their opinion, however, the expression "philosophical" becomes an accusation.

The real Christian life - according to the Reformers - is not the life of an obese Dominican monk, like St. Thomas Aquinas, spending his time contemplating and reading the Holy Bible and Aristotle. More pleasant to God is a simple, ordinary bustle of man striving for the material wealth of the family and prosperity of the business.

Interestingly, this type of criticism, which was originally an intra-religious debate of competing types of spirituality, finally served as an argument for the opponents of all religions. Rhetoric similar to that, which was used by reformers against the monks and nuns, served as a weapon against the Christian faith itself. ${ }^{16}$

${ }^{14}$ Charles Taylor, "The Immanent Counter-Enlightenment”, in: Canadian Political Philosophy: Contemporary Reflections, eds. Ronald Beiner, Wayne Norman (Oxford University Press, 2001), 386-400.

${ }^{15}$ Karłowicz, Sokrates, 18.

16 Taylor, "The Immanent". 
In order to renew the classical virtue in opposition to its scholastic interpretation, the Aristotelian belief that the purpose of the city was virtue was rejected. Virtue is desired, but not for itself but for the good of the city. The city is not there to serve virtue, but the virtue is there to be for the city. We can say that this conclusion is the foundation of modern thought. Virtue is desired because of the city and to serve its good. Therefore, political decisions cannot be judged in moral categories.

\section{The purpose of the city}

What is the purpose of the city? Why constituting the sphere of freedom is the purpose of politics? The modern answer is known and obvious, even trivial: political freedom is to serve human survival, satisfying needs, relieving anxiety, allowing prosperity. Machiavelli and Hobbes were the first to formulate this postulate and, therefore, they can be rightly regarded as fathers or founders of modernity ${ }^{17}$.

Virtue is useful for the city, and the city is to serve human good. Created, often in good faith, attempts to "justify" virtue by demonstrating its usefulness actually undermine the foundations of ethics. Demonstrating the usefulness of ethics does not lead to its restoration but to its instrumentalisation, and then - to its destruction. From the perspective of education, understanding virtue as something "good itself" has been substituted by the instrumental understanding of virtue; honesty is nothing but the best policy, the most effective policy in trade. Be "good" because it pays off. This is the first stage of the "educational breakthrough": young people must be convinced about the usefulness and the benefits of moral norms. They have to follow the rules of ethics, because it is beneficial to them.

However, this is only the first step. The next one is the conclusion that education of an individual is not as important as it was previously thought. The focus on institutions is much more effective. It is necessary to design the society and its institutions so that it does not pay to be unethical. In contrary to the perspective of the classical philosophers, a good city or state can do without individual education aiming at the proper order of the human soul. It is enough to appeal to individual interests. "Not enlightened", irrational self-interest should be replaced by enlightened self-interest. The realisation

${ }^{17}$ Leo Strauss, An Introduction to Political Philosophy: ten essays by Leo Strauss, ed. Hilail Gildin (Detroit: Wayne State University Press, 1989). 
of a good state will then not only be possible, but even very likely, or finally certain. To create such a community, we do not need well-formed noble gentlemen, whose virtue is a reflection of the virtues of the philosophers. A state could even be created by devils - as Kant assumed - provided that they were guided by a well-understood self-interest. ${ }^{18}$ Devils obviously do not need moral education.

In the modern state, ancient virtue initially subordinated to the interests of the state ultimately becomes unnecessary. Vices, such as egoistic focus on one's own interests, will become a new kind of "virtue". According to Allan Bloom, "The great change is that a good man used to be the one who cares for others, as opposed to the man who cares exclusively for himself. Now the good man is the one who knows how to care for himself, as opposed to the man who does not." 19

According to Hobbes, real people, in contrast to Aristotle's perspective, are aggressive and cowardly egoists. Only the fear of death, the desire for comfort and the hope of obtaining it can lead to peace. These tendencies: the fear of death and the desire for comfort are the causes of conflict, but concurrently they are recognised as passions that allow peace. They are the cause of the disease, but they can and should also become a cure. Desire for fame, identified with vanity, can never be subdued. Therefore, the "aristocratic" aspirations should be eliminated in another way. The task of reason is to find a means that helps to make it possible to redirect and strengthen fear of death and desire for comfort so as to abolish the destructive effects of hubris and desire for fame.

There is no place for ancient virtues. They have no political or moral value. The greatest advantage of man is the ability of peaceful coexistence motivated by self interest. Egoism is no longer a vice requiring abolition. It is now becoming the basis, condition, and justification for the new virtue. Private vice transforms into public virtue.

From this perspective everyone is guided only by individual interests so the goal of education is to enlighten people as to how they can reasonably satisfy their own needs. Modern education enables transition from an unenlightened to enlightened self-interest. Classical and Christian education understood as the shaping of the proper order of the soul in the perspective

18 Immanuel Kant, Perpetual Peace. A Philosophical Essay (2016), 154, https://www. gutenberg.org/files/50922/50922-h/50922-h.htm\#Page_106 [access: 28.06.2019].

19 Allan Bloom, The Closing of The American Mind (New York: Simon and Schuster, 1987), 178. 
of human nature become less important. Creating the right kind of institution and taking care of their functioning began to be regarded as something more important than shaping the character by liberal education. The institutions and the free market are the most important. The quality of the state is not created by the nobility of citizens, but rather by the efficiency of administration and following procedures.

\section{The method and progress}

Thanks to the discovery of the scientific method, modernity was able to believe in the idea of progress. The concept of the method is typical to modern science. The method compensates the natural differences between minds, and everyone can learn it. This leads to a conviction about the incomparable superiority of modern, enlightened people over their ancestors. According to Strauss, the beginning is the most imperfect, and the perfection can only be found at the end. From this perspective, the past has no right to deserve respect. Antiquity deserves contempt, or perhaps contempt mixed with compassion $^{20}$.

One of the most important reasons for this contempt is the modern denial of the allegedly naive faith of classical and Christian philosophers in the need to educate the human character. Moral principles and references to them, described scornfully as "moralising" or "preaching", are ineffective. Everybody, including politicians, economists, intellectuals, educators and theatre or film critics, knows it today. The worst accusation that can be made is "moralising" or "preaching" or "judging" anyone. Nobody believes in the power of virtue today. As classical and Christian solutions have not produced the expected results, it is important to turn to institutions, economics and history in which progress is evident ${ }^{21}$.

Egalitarianism proclaiming that all perspectives are equal wins. The educator, like a door-to-door salesman, can then offer an increasingly wide choice of lifestyles, ethical and religious systems, and even diverse cultures to the young man. However, the educator should not and cannot answer the question about the criteria of choosing a particular option. It is his duty to ad-

\footnotetext{
${ }^{20}$ Strauss, An Introduction.

${ }^{21}$ Eric Voegelin, From Enlightenment to Revolution (Durham, North Carolina: Duke University Press, 1975).
} 
mit to total ignorance in this matter. The question about the best kind of life is rejected and forbidden before it appears. Relativism is perceived not only as an epistemological stance, but as a kind of moral obligation of the educator.

Liberal education, in its original meaning given by Plato, appears to be particularly important in modern liberal democracy, which tends to turn into mass consumer democracy. Is freedom important because it allows virtue or rather is free choice to be regarded as good in itself, regardless of what is chosen? The answer to this question is different in the aforementioned standpoints, and, concurrently, to a large extent, it determines our understanding of the purpose and sense of education. Sometimes, in consequence, not always pronounced explicitly, it even questions the need of education, including moral education.

The order characteristic to the Western culture was conditioned by these two visions of the world. This order is now breaking down. The classical natural law theory has been questioned. In Polish reality, the Catholic Church is the most important supporter of this concept, which is why the belief that this is a "church" concept has become established in the general consciousness. Recalling both Christian thinkers and authors who do not refer to Christianity allows us to see the universal qualities of the classical natural law theory. Education cannot evade the duty to take care of the threatened order of the Western world. This duty is best fulfilled today by saving the legacy of Greek and Christian philosophy from forgetfulness and by passing it to the young generations. The legacy has been continued and creatively developed by thinkers in the classical natural law theory. Whilst under the current circumstances it is not an easy task, one must hope that it is not beyond our capabilities.

\section{References}

Baumgartner, Hans-Michael. Rozum skończony. Ku rozumieniu filozofii przez siebie sama [Endliche Vernunft. Zur Verständigung der Philosophie über sich selbst], trans. Andrzej Maciej Kaniowski. Warszawa: Oficyna Naukowa, 1996.

Bloom, Allan. The Closing of the American Mind. New York: Simon and Schuster, 1987.

Boethius, Anicius Manlius Severinus. The Consolation of Philosophy, trans. W. V. Cooper (2009). https://www.exclassics.com/consol/consol.pdf [access: 5.11.2019]. Gadamer, Hans-Georg. The Idea of the Good in Platonic-Aristotelian Philosophy. Yale University Press, 1986. 
Hadot, Pierre. Czym jest filozofia starożytna? [Qu'est-ce que la philosophie antique?], trans. Piotr Domański. Warszawa: Fundacja Aletheia, 2000.

Hadot, Pierre. Filozofia jako ćwiczenie duchowe [Exercices spirituels et philosophie antique], trans. Piotr Domański. Warszawa: Fundacja Aletheia, 2003.

Jaeger, Werner. Early Christianity and Greek Paideia. Harvard University Press, 1985.

Kant, Immanuel. Perpetual Peace. A Philosophical Essay (2016). https://www.gutenberg.org/files/50922/50922-h/50922-h.htm\#Page_106 [access: 28.06.2019].

Karłowicz, Dariusz. Sokrates i inni święci. Warszawa: Wydawnictwo Fronda i Ośrodek Myśli Politycznej, 2005.

Kasjan, Jan. Rozmowy z Ojcami [Collationes patrum XXIV], trans. Arkadiusz Nocon. Kraków: Wydawnictwo Benedyktynów Tyniec, 2002.

Ratzinger, Joseph. Truth and Tolerance. Christian Belief and World Religions. San Francisco: Ignatius Press, 2004.

Strauss, Leo. An Introduction to Political Philosophy: ten essays by Leo Strauss, ed. Hilail Gildin. Detroit: Wayne State University Press, 1989.

Strauss, Leo. Liberalism Ancient and Modern. Chicago-London: The University of Chicago Press, 1995.

Strauss, Leo. Natural Right and History. Chicago: The University of Chicago Press, 1971.

Taylor, Charles. "The Immanent Counter-Enlightenment". In: Canadian Political Philosophy: Contemporary Reflections, eds. Ronald Beiner, Wayne Norman, 386-400. Oxford University Press, 2001.

Voegelin, Eric. From Enlightenment to Revolution. Durham, North Carolina: Duke University Press, 1975. 
